\title{
The Study of Defects on Galvanically Plated Polymeric Parts
}

Zuzana Andrsova ${ }^{1}$, Petr Podzimek ${ }^{2}$, Pavel Kejzlar ${ }^{1}$

${ }^{1}$ Institute for nanomaterials, advanced technologies and innovations, Technical university of Liberec, Studentska 1402/2, Liberec 1, 461 17. Email: zuzana.andrsova1@tul.cz, pavel.kejzlar@tul.cz.

${ }^{2}$ Funchem, Snehurcina 712/77, Liberec 15, 460 15. Emai: podzimek@funchem.cz.

Galvanic plating of polymeric structural parts is widely used in many industrial branches, e.g. in automotive. Minor errors in their manufacturing process are responsible for presence of surface defects. These defects, especially in the case of visual and decorative parts, are unacceptable. This paper demonstrates the usage of optical and electron microscopy to reveal and solve common problems in industrial production. Different types of galvanic plating defects on injection molded parts made of ABS, PC/ABS and PA manifest themselves by different ways.

Keywords: Microscopy, Coating, Analysis, Defect, Polymer

\section{Acknowledgement}

The results of this project LO1201 were obtained with through the financial support of the Ministry of Education, Youth and Sports in the framework of the targeted support of the "National Programme for Sustainability I" and the OPR\&DI project Centre for Nanomaterials, Advanced Technologies and Innovation CZ.1.05/2.1.00/01.0005.

\section{References}

[1] [online] POKORNY, P., SVADLENA, J., NOVAK, P., SZELAG, P., SUBERT, L. (2014). The assesment of causes of formation of defective metallic coatings on the ABS polymer system (2014). Corrosion and material protection, vol. 58 (3), p. 75-83. ISSN 1804-1213. Available at http://www.degruyter.com/downloadpdf/j/kom.2014.58.issue-3/kom-2014-0014/kom-2014-0014.xml. Cited 20.8.2016.

[2] [online] SUBERT, L. (2014). Polymers and galvanic plating. Tribotechnika, vol. 2/2014, p. 40-43. Available at http://www.tribotechnika.sk/tribotechnika-22014/plasty-a-galvanicka-povrchova-uprava.html. Cited 20.8.2016.

[3] [online] OSTRA, V. (2009). Plating of polymers. Povrchari, vol. 9, p. 4-6. Available at http:// http://www.povrchari.cz/. Cited 20.8.2016.

[4] MOBIUS, A., TOLLS, E. (1999). Plating on plastic - new developments in the field of chemistry. Transactions of the Institute of metal finishing, vol 77, p. B9-B11.

[5] RABILlOUD, G. (2000). High-performance polymers: chemistry and applications. Paris: Editions Technip, ISBN 2710807203.

[6] MALLORY, G. O., HAJDU, J. B. (2009). Electroless plating: fundamentals and applications. Reprint ed. Norwich, NY: Knoyes Publications/William Andrew Publishing. ISBN 9780815512776.

[7] DURNEY, L. J. (1996). Electroplating engineering handbook. 4th ed. London: Chapman \& Hall. ISBN 9780412741104.

[8] ASM handbook: Surface engineering (1994). Vol. 5. Materials Park, Ohio: ASM International. ISBN 9780871703842.

[9] KEJZLAR, P., ŠVEC, M., MACAJOVÁ, E. (2014). The usage of backscattered electrons in scanning electron microscopy. In: Manufacturing Technology, Vol. 14, No. 3, pp. 333-336.

[10] TREGLER, M., KEJZLAR, P., PILVOUSEK, T., ANDRŠOVÁ, Z., VOLESKÝ, L. (2016). The Study of Deformation Behaviour of DC06 Deep Drawing Steel (2016). In: Manufacturing Technology Vol. 16, No. 1, pp. 284289.

[11] KEJZLAR, P., ŠVEC, M., ANDRŠOVÁ, Z., ŠVEC, M. (2015). Structure of Al-targets Used for PVD Coating in Jewellery (2015). In: Manufacturing Technology, Vol. 5, No. 4, pp. 553-557. 